\title{
Determination of land surface heat fluxes over heterogeneous landscape of the Tibetan Plateau by using the MODIS and in situ data
}

\author{
Y. Ma ${ }^{1}$, L. Zhong ${ }^{1,2}$, B. Wang ${ }^{1,3}$, W. Ma ${ }^{4}$, X. Chen ${ }^{1,2,3}$, and M. Li ${ }^{4}$ \\ ${ }^{1}$ Key Laboratory of Tibetan Environment Changes and Land Surface Processes, Institute of Tibetan Plateau Research, \\ Chinese Academy of Sciences, Beijing, China \\ ${ }^{2}$ International Institute for Geo-Information Science and Earth Observation, Enschede, The Netherlands \\ ${ }^{3}$ Graduate University of Chinese Academy of Sciences, Beijing 100049, China \\ ${ }^{4}$ Cold and Arid Regions Environmental and Engineering Research Institute, Chinese Academy of Sciences, \\ Lanzhou 730000, China
}

Received: 29 May 2011 - Published in Atmos. Chem. Phys. Discuss.: 8 July 2011

Revised: 23 September 2011 - Accepted: 8 October 2011 - Published: 21 October 2011

\begin{abstract}
In this study, a parameterization methodology based on MODIS (Moderate Resolution Imaging Spectroradiometer) and in situ data is proposed and tested for deriving the regional surface reflectance, surface temperature, net radiation flux, soil heat flux, sensible heat flux and latent heat flux over heterogeneous landscape. As a case study, the methodology was applied to the Tibetan Plateau area. Four images of MODIS data (30 January 2007, 15 April 2007, 1 August 2007 and 25 October 2007) were used in this study for the comparison among winter, spring, summer and autumn. The derived results were also validated by using the "ground truth" measured in the stations of the Tibetan Observation and Research Platform (TORP). The results show that the derived surface variables (surface reflectance and surface temperature) and surface heat fluxes (net radiation flux, soil heat flux, sensible heat flux and latent heat flux) in four different seasons over the Tibetan Plateau area are in good accordance with the land surface status. These parameters show a wide range due to the strong contrast of surface features over the Tibetan Plateau. Also, the estimated land surface variables and surface heat fluxes are in good agreement with the ground measurements, and all their absolute percent difference (APD) is less than $10 \%$ in the validation sites. It is therefore concluded that the proposed methodology is successful for the retrieval of land surface variables and surface
\end{abstract}

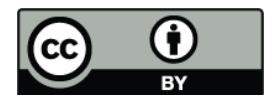

Correspondence to: Y. M. Ma (ymma@itpcas.ac.cn) heat fluxes using the MODIS and in situ data over the Tibetan Plateau area. The shortage and further improvement of the methodology were also discussed.

\section{Introduction}

The Tibetan Plateau contains the world's highest elevation (average elevation about $4000 \mathrm{~m}$ ) relief features, some reaching into the mid-troposphere. It represents an extensive mass extending from subtropical to middle latitudes and is spanning over 25 degrees of longitude. Figure 1 shows the geographic location and topographic characteristics of the TP. Because of its topographic character, the plateau surface absorbs a large amount of solar radiation energy, and undergoes dramatic seasonal changes of surface heat and water fluxes (e.g., Ye and Gao, 1979; Ye, 1981; Yanai et al., 1992; Ye and Wu, 1998; Ma et al., 2002a; Ma and Tsukamoto, 2002; Hsu and Liu, 2003; Yang et al., 2004; Ma et al., 2006; Sato and Kimura, 2007; Ma et al., 2008; Cui and Graf, 2009; Zhong et al., 2010). In order to understand the effect of the Tibetan Plateau on the climatic change over China, east Asia and even the global, one has to get the regional distribution of surface heat fluxes over whole Tibetan Plateau.

Remote sensing from satellites however offers the possibility to derive regional distribution of surface heat fluxes over heterogeneous land surface of the Tibetan Plateau in combination with sparse field experimental stations. The

Published by Copernicus Publications on behalf of the European Geosciences Union. 


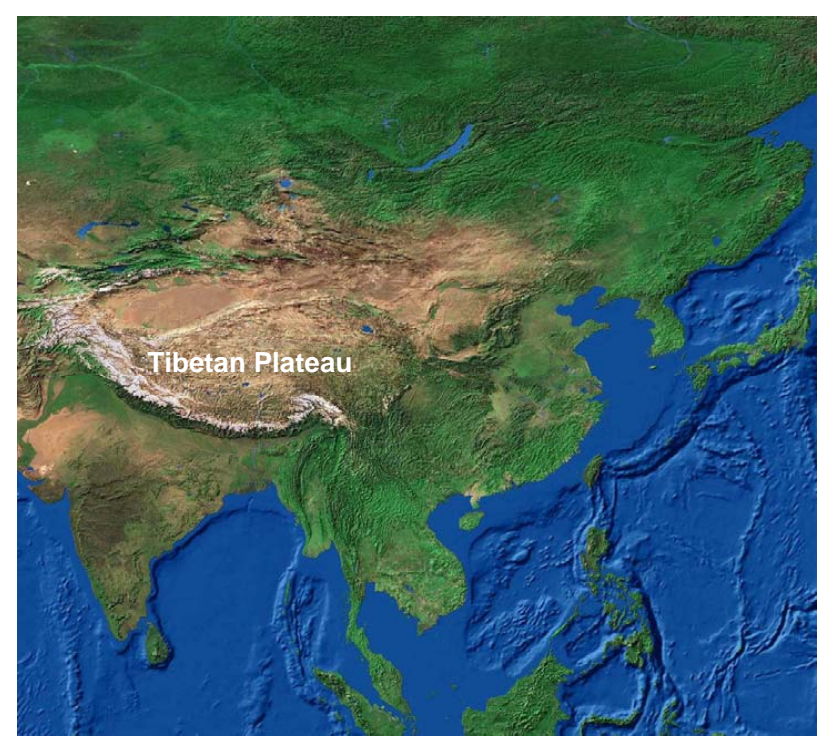

Fig. 1. The location and landscape of the Tibetan Plateau.

regional distributions of surface heat flux(net radiation flux, soil heat flux, sensible heat flux and latent heat flux) have already been gotten by some researchers over the Tibetan Plateau area, but the results were only in meso-scale area till now (e.g. Ma et al., 2003, 2006, 2009). The objective of this study is to explore the feasibility of up-scaling the point land surface variables (surface reflectance and surface temperature) and surface heat fluxes to yield whole Plateau spatial distributions with the aid of MODIS and in situ data.

\section{Theory and scheme}

The general concept of the methodology is shown in a diagram (Fig. 2). The surface reflectance for short-wave radiation $r_{0}(\mathrm{x}, \mathrm{y})$ is retrieved from MODIS data with the atmospheric correction, using land surface and aerological observation data (Zhong, 2007). The land surface temperature $T_{\text {sfc }}(\mathrm{x}, \mathrm{y})$ is also derived from MODIS data, land surface and aerological observation data (Zhong et al., 2010). The radiative transfer model MODTRAN (Berk et al., 1989) compute the downward short-wave and long-wave radiation at the surface (Ma and Tsukamoto, 2002). With these results the regional surface net radiation flux $R_{n}(\mathrm{x}, \mathrm{y})$ is determined. The regional soil heat flux $G_{0}(\mathrm{x}, \mathrm{y})$ is estimated from $R_{n}(\mathrm{x}, \mathrm{y})$ and field observations over the Tibetan Plateau. The regional sensible heat flux $H(\mathrm{x}, \mathrm{y})$ is estimated from $T_{\mathrm{sfc}}(\mathrm{x}, \mathrm{y})$, surface and aerological data with the aid of so-called "tile approach" (Ma et al., 2010), and the regional latent heat flux $\lambda E(\mathrm{x}, \mathrm{y})$ can be derived as the residual of the energy budget theorem for land surface.

\subsection{Net radiation flux}

The regional net radiation flux can be derived from

$R_{n}(\mathrm{x}, \mathrm{y})=\left(1-r_{0}(\mathrm{x}, \mathrm{y})\right) \cdot K_{\downarrow}(\mathrm{x}, \mathrm{y})+L_{\downarrow}(\mathrm{x}, \mathrm{y})-\varepsilon_{0}(\mathrm{x}, \mathrm{y}) \sigma T_{\mathrm{sfc}}^{4}(\mathrm{x}, \mathrm{y})$

where $r_{0}(\mathrm{x}, \mathrm{y})$ and $T_{\mathrm{sfc}}(\mathrm{x}, \mathrm{y})$ are surface reflectance and surface temperature respectively. They can be derived from MODIS data with the atmospheric correction, using land surface and aerological observation data (Zhong, 2007; Zhong et al., 2010). Surface emissivity of $\varepsilon_{0}(\mathrm{x}, \mathrm{y})$ in Eq. (1) is a function of the vegetation coverage $P_{\mathrm{v}}(\mathrm{x}, \mathrm{y})$. It can be derived from the model of Valor and Caselles (1996) i.e.

$$
\begin{aligned}
\varepsilon_{0}(\mathrm{x}, \mathrm{y})= & \varepsilon_{v}(\mathrm{x}, \mathrm{y}) P_{\mathrm{v}}(\mathrm{x}, \mathrm{y})+\varepsilon_{g}(\mathrm{x}, \mathrm{y})\left(1-P_{\mathrm{v}}(\mathrm{x}, \mathrm{y})\right)+4 \\
& <d \varepsilon>\left(1-P_{\mathrm{v}}(\mathrm{x}, \mathrm{y})\right) P_{\mathrm{v}}(\mathrm{x}, \mathrm{y})
\end{aligned}
$$

where $\varepsilon_{v}(\mathrm{x}, \mathrm{y})=0.985( \pm 0.007)$ and $\varepsilon_{g}(\mathrm{x}, \mathrm{y})=0.960$ $( \pm 0.010)$ are surface emissivity for full vegetation and bare soil respectively, $<d \varepsilon>=0.015( \pm 0.008)$ is the error, and vegetation coverage (Carlson and Ripley, 1997)

$P_{\mathrm{v}}(\mathrm{x}, \mathrm{y})=\left[\frac{\mathrm{NDVI}(\mathrm{x}, \mathrm{y})^{-} \mathrm{NDVI}_{\mathrm{min}}}{\mathrm{NDVI}_{\mathrm{max}}-\mathrm{NDVI}_{\mathrm{min}}}\right]^{2}$

where $\mathrm{NDVI}_{\min }$ and $\mathrm{NDVI}_{\max }$ are the NDVI values for bare soil and full vegetation, respectively.

The incoming long-wave radiation flux $L_{\downarrow}(\mathrm{x}, \mathrm{y})$ and incoming short-wave radiation flux $K_{\downarrow}(\mathrm{x}, \mathrm{y})$ in Eq. (1) can be calculated from radiative transfer model MODTRAN directly (Ma and Tsukamoto, 2002).

\subsection{Soil heat flux}

The regional surface soil heat flux $G_{0}(\mathrm{x}, \mathrm{y})$ can be determined by (Choudhury and Monteith, 1988)

$G_{0}(\mathrm{x}, \mathrm{y})=\rho_{\mathrm{s}} c_{\mathrm{s}}\left[\left(T_{\mathrm{sfc}}(\mathrm{x}, \mathrm{y})-T_{\mathrm{s}}(\mathrm{x}, \mathrm{y})\right] / r_{\mathrm{sh}}(\mathrm{x}, \mathrm{y})\right.$

where $\rho_{\mathrm{S}}$ is soil dry bulk density, $c_{\mathrm{S}}$ is soil specific heat, $T_{S}(\mathrm{x}, \mathrm{y})$ stands for soil temperature at a determined depth, $r_{\mathrm{sh}}(\mathrm{x}, \mathrm{y})$ represents soil heat transfer resistance.

$G_{0}$ (x,y)can not directly be mapped from satellite measurements through Eq. (4). The difficulty is to derive $r_{\mathrm{sh}}(\mathrm{x}, \mathrm{y})$ and $T_{\mathrm{s}}$ (x,y) (Bastiaanssen, 1995; Wang et al., 1995; Ma and Tsukamoto, 2002; Ma et al., 2002b; Ma et al., 2003; Ma et al., 2006; Ma et al., 2007; Gao et al., 2010). To calculate the values of $G_{0}(\mathrm{x}, \mathrm{y})$ solely from remote sensed data requires that it is to be made proportional to another term in the energy balance equation. A good candidate is $R_{n}(\mathrm{x}, \mathrm{y})$ (Jackson et al., 1985; Choudhury et al., 1987; Kustas and Daughtry, 1990; Bastiaanssen, 1995; Ma and Tsukamoto, 2002; Ma et al., 2003, 2006; Gao et al., 2010). Based on the in situ data observed in the TP area, Ma et al. (2002b) proposed an equation to derive regional soil heat flux $G_{0}(\mathrm{x}, \mathrm{y})$ from regional 


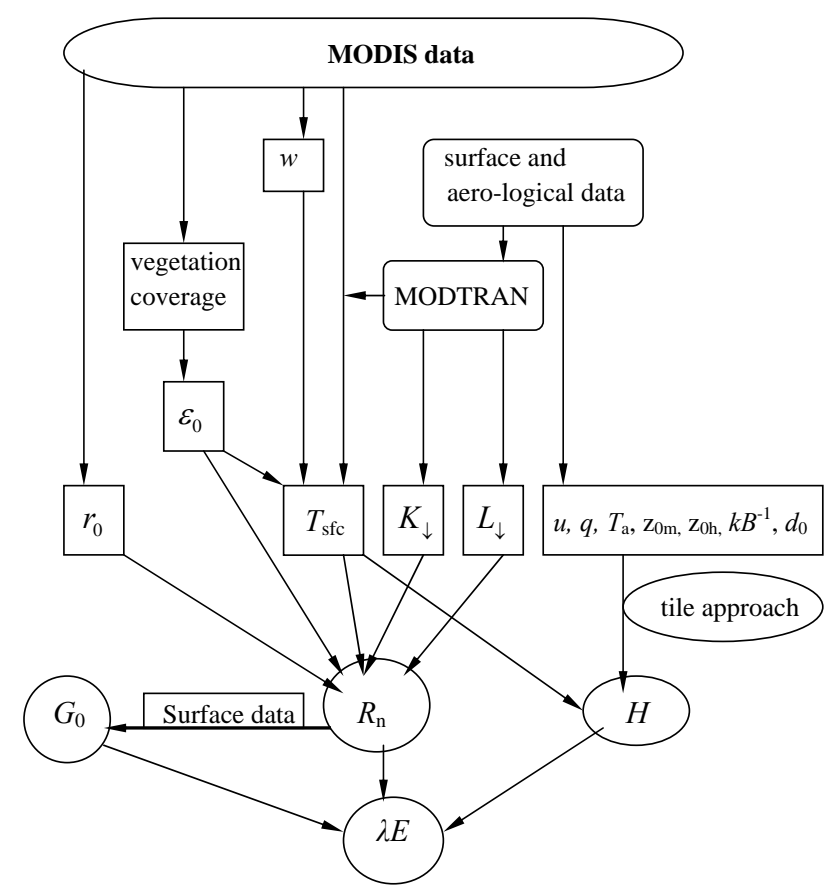

Fig. 2. The diagram of parameterization procedure to determine surface reflectance, surface temperature, net radiation flux, soil heat flux, sensible heat flux and latent heat flux by combining MODIS data with field observations.

net radiation flux $R_{n}(\mathrm{x}, \mathrm{y})$ based the in situ data over the Tibetan Plateau. It is

$G_{0}(\mathrm{x}, \mathrm{y})=0.35462( \pm 0.00235) R_{n}(\mathrm{x}, \mathrm{y})-47.79008( \pm 0.70005)(5)$

Eq. (5) will be used to determine the regional distribution of soil heat flux in the TP area in this study.

\subsection{Sensible heat flux}

The sensible heat flux $H$ can be estimated with a bulk transfer equation written in the form (Montheith, 1973)

$H=\rho c_{p} \frac{T_{0}-T_{\mathrm{a}}}{r_{\mathrm{ah}}}$

where $r_{\text {ah }}$ is aerodynamic resistance for heat transfer between land surface and reference height, $T_{0}$ is the surface temperature, $T_{\mathrm{a}}$ is the air temperature at the reference height, $\rho$ is the air density, and $c_{p}$ is the air specific heat at constant pressure.

In order to determine the regional distribution of sensible heat flux $H(\mathrm{x}, \mathrm{y})$ over the Tibetan Plateau, the Tile approach (Ma et al., 2010) will be used here. In the Tile approach, the reference height $z_{\text {ref }}$ is taken within Surface Layer (SL). Then, using the satellite measurements at the surface and the SL observations on a "tile" at and below the reference height (e.g. $20 \mathrm{~m}$ ), the heat fluxes over a heterogeneous landscape can be estimated. Firstly, surface reflectance $r_{0}$, surface temperature $T_{\mathrm{sfc}}$ vegetation coverage $P_{\mathrm{v}}$ and surface emissivity $\varepsilon_{0}$ etc. at the surface are derived from satellite measurements. Secondly, SL observations on a tile: wind speed $u$, air temperature $T_{\mathrm{a}}$ and specific humidity $q$ at the reference height are carried out. Zero-plane displacement $d_{0}$, aerodynamic roughness length $z_{0 \mathrm{~m}}$ and thermodynamic roughness length $z_{0 h}$, the excess resistance for heat transportation $k B^{-1}$ and the like in SL below the reference height over the $i$-tile are used to estimate the sensible heat flux $H$ (Fig. 2).

Hence, in mathematical terms:

$$
\begin{aligned}
& H_{1}(\mathrm{x}, \mathrm{y})=\rho c_{p} \frac{\left[T_{0}(\mathrm{x}, \mathrm{y})-T_{\mathrm{a} 1}\right]}{r_{\mathrm{ah} 1}}, \\
& H_{2}(\mathrm{x}, \mathrm{y})=\rho c_{p} \frac{\left[T_{0}(\mathrm{x}, \mathrm{y})-T_{\mathrm{a} 2}\right]}{r_{\mathrm{ah} 2}}, \\
& \ldots \ldots \\
& H_{n}(\mathrm{x}, \mathrm{y})=\rho c_{p} \frac{\left[T_{0}(\mathrm{x}, \mathrm{y})-T_{\mathrm{an}}\right]}{r_{\mathrm{ahn}}}
\end{aligned}
$$

Therefore, $H$ over whole Tibetan Plateau area can be derived from:

$H(\mathrm{x}, \mathrm{y})=\sum_{i=1}^{n} a(i) H_{i}(\mathrm{x}, \mathrm{y})$

where $a(i)$ is the fractional ratio of each "tile" for the Tibetan Plateau, and it can be determined form the satellite images. $H_{1}(\mathrm{x}, \mathrm{y}), H_{2}(\mathrm{x}, \mathrm{y}) \ldots$, and $H_{n}(\mathrm{x}, \mathrm{y})$ are sensible heat flux on each "tile", $T_{a 1}, T_{a 2} \ldots$, and $T_{\mathrm{a} 2}$ are air temperature at the reference height on each "tile", $r_{\mathrm{ah} 1}, r_{\mathrm{ah} 2} \ldots$, and $r_{\mathrm{ahn}}$ are aerodynamic resistance for heat transfer between land surface and reference height on each "tile". $r_{\mathrm{ah} 1}, r_{\mathrm{ah} 2} \ldots$, and $r_{\text {ahn }}$ can be determined from the eddy diffusion coefficients for heat transport between the land surface and the reference height (Ma et al., 2010).

\subsection{Latent heat flux}

The regional latent heat flux $\lambda E(\mathrm{x}, \mathrm{y})$ can be derived as the residual of the energy budget theorem for land surface based on the condition of zero horizontal advection, i.e.,

$$
\lambda E(\mathrm{x}, \mathrm{y})=R_{n}(\mathrm{x}, \mathrm{y})-H(\mathrm{x}, \mathrm{y})-G_{0}(\mathrm{x}, \mathrm{y})
$$

\section{Cases study and validation}

Four images of MODIS data (30 January 2007, 15 April 2007, 1 August 2007 and 25 October 2007) will be used in this study for the comparison among winter, spring, summer and autumn.

Figure 3 shows the distribution maps of surface reflectance and surface temperature over the Tibetan Plateau area. Using Eqs. (1) and (9), the distributions of soil heat flux and latent heat flux are shown in Fig. 4. The distribution maps of surface reflectance, surface temperature, soil heat flux and latent heat flux are based on $2823 \times 1441$ 
Table 1. Comparison of the derived surface reflectance, surface temperature, net radiation flux and soil heat flux(Cal.) versus the values measured (Meas.) at the Tibetan Plateau with absolute percent difference (APD).

\begin{tabular}{|c|c|c|c|c|c|c|c|c|c|c|c|c|}
\hline \multirow{2}{*}{$\begin{array}{l}\text { January } \\
\text { Sites }\end{array}$} & \multicolumn{3}{|c|}{$r_{0(-)}$} & \multicolumn{3}{|c|}{$T_{\mathrm{S}}\left({ }^{\circ} \mathrm{C}\right)$} & \multicolumn{3}{|c|}{$R_{n}\left(\mathrm{Wm}^{-2}\right)$} & \multicolumn{3}{|c|}{$G_{0}\left(\mathrm{Wm}^{-2}\right)$} \\
\hline & Cal. & Meas. & APD & Cal. & Meas. & APD & Cal. & Meas. & APD & Cal. & Meas. & APD \\
\hline Haibei & 0.21 & 0.22 & $4.5 \%$ & 20.0 & 19.0 & $5.3 \%$ & 347 & 331 & $4.8 \%$ & 64 & 59 & $8.5 \%$ \\
\hline Maqu & 0.22 & 0.23 & $4.3 \%$ & 19.0 & 18.0 & $5.6 \%$ & 383 & 353 & $8.5 \%$ & 93 & 85 & $9.4 \%$ \\
\hline D105 & 0.26 & 0.25 & $4.0 \%$ & 11.0 & 10.0 & $10.0 \%$ & 351 & 321 & $9.3 \%$ & 99 & 91 & $8.8 \%$ \\
\hline Amdo & 0.21 & 0.23 & $8.7 \%$ & 16.0 & 15.0 & $6.7 \%$ & 382 & 354 & $7.9 \%$ & 96 & 92 & $4.3 \%$ \\
\hline NPAM & 0.18 & 0.19 & $5.3 \%$ & 15.0 & 14.0 & $7.1 \%$ & 404 & 413 & $2.2 \%$ & 68 & 62 & $9.7 \%$ \\
\hline BJ & 0.25 & 0.27 & $7.4 \%$ & 2.0 & 2.0 & $0.0 \%$ & 311 & 285 & $9.1 \%$ & 94 & 87 & $8.0 \%$ \\
\hline NAMOR & 0.43 & 0.41 & $4.9 \%$ & -2.0 & -2.0 & $0.0 \%$ & 358 & 343 & $4.4 \%$ & 72 & 66 & $9.1 \%$ \\
\hline QOMS & 0.28 & 0.29 & $3.4 \%$ & 6.0 & 6.0 & $0.0 \%$ & 367 & 337 & $8.9 \mathrm{v} \%$ & 103 & 94 & $9.6 \%$ \\
\hline SETS & 0.18 & 0.19 & $5.3 \%$ & 18.0 & 19.0 & $5.3 \%$ & 436 & 457 & $4.6 \%$ & 54 & 50 & $8.0 \%$ \\
\hline April & \multicolumn{3}{|c|}{$r_{0(-)}$} & \multicolumn{3}{|c|}{$T_{\mathrm{S}}\left({ }^{\circ} \mathrm{C}\right)$} & \multicolumn{3}{|c|}{$R_{n}\left(\mathrm{Wm}^{-2}\right)$} & \multicolumn{3}{|c|}{$G_{0}\left(\mathrm{Wm}^{-2}\right)$} \\
\hline Sites & Cal. & Meas. & APD & Cal. & Meas. & APD & Cal. & Meas. & APD & Cal. & Meas. & APD \\
\hline Haibei & 0.24 & 0.22 & $9.1 \%$ & 14.0 & 15.0 & $6.7 \%$ & 603 & 621 & $2.9 \%$ & 86 & 79 & $8.9 \%$ \\
\hline Maqu & 0.24 & 0.23 & $4.3 \%$ & 21.0 & 23.0 & $8.7 \%$ & 449 & 431 & $4.2 \%$ & 90 & 82 & $9.7 \%$ \\
\hline D105 & 0.25 & 0.24 & $4.2 \%$ & 13.0 & 12.0 & $8.3 \%$ & 352 & 323 & $9.0 \%$ & 86 & 80 & $7.5 \%$ \\
\hline Amdo & 0.23 & 0.21 & $9.5 \%$ & 29.0 & 27.0 & $7.4 \%$ & 410 & 388 & $5.7 \%$ & 89 & 83 & $7.2 \%$ \\
\hline NPAM & 0.19 & 0.18 & $5.6 \%$ & 35.0 & 34.0 & $2.9 \%$ & 606 & 644 & $5.9 \%$ & 91 & 85 & $7.1 \%$ \\
\hline BJ & 0.23 & 0.22 & $4.5 \%$ & 29.0 & 27.0 & $7.4 \%$ & 441 & 432 & $2.1 \%$ & 108 & 101 & $6.9 \%$ \\
\hline NAMOR & 0.22 & 0.21 & $4.8 \%$ & 17.0 & 16.0 & $6.3 \%$ & 522 & 515 & $1.4 \%$ & 96 & 92 & $4.3 \%$ \\
\hline QOMS & 0.27 & 0.26 & $3.8 \%$ & 20.0 & 21.0 & $4.8 \%$ & 475 & 466 & $1.9 \%$ & 139 & 133 & $4.5 \%$ \\
\hline SETS & 0.19 & 0.20 & $5.0 \%$ & 29.0 & 32.0 & $9.4 \%$ & 611 & 648 & $5.7 \%$ & 94 & 87 & $8.0 \%$ \\
\hline August & \multicolumn{3}{|c|}{$r_{0(-)}$} & \multicolumn{3}{|c|}{$T_{\mathrm{S}}\left({ }^{\circ} \mathrm{C}\right)$} & \multicolumn{3}{|c|}{$R_{n}\left(\mathrm{Wm}^{-2}\right)$} & \multicolumn{3}{|c|}{$G_{0}\left(\mathrm{Wm}^{-2}\right)$} \\
\hline Sites & Cal. & Meas. & APD & Cal. & Meas. & APD & Cal. & Meas. & APD & Cal. & Meas. & APD \\
\hline Haibei & 0.23 & 0.22 & $4.5 \%$ & 21.0 & 22.0 & $4.5 \%$ & 358 & 350 & $2.3 \%$ & 88 & 82 & $7.3 \%$ \\
\hline Maqu & 0.18 & 0.19 & $5.3 \%$ & 24.0 & 25.0 & $4.0 \%$ & 694 & 639 & $8.6 \%$ & 138 & 126 & $9.5 \%$ \\
\hline D105 & 0.22 & - & - & 19.0 & - & - & 633 & - & - & 110 & 101 & $8.9 \%$ \\
\hline Amdo & 0.19 & - & - & 20.0 & - & - & 686 & - & - & 126 & - & - \\
\hline NPAM & 0.14 & 0.13 & $7.7 \%$ & 20.0 & 19.0 & $5.3 \%$ & 737 & 780 & $5.5 \%$ & 115 & 108 & $6.5 \%$ \\
\hline BJ & 0.15 & 0.16 & $6.3 \%$ & 24.0 & 23.0 & $4.3 \%$ & 702 & 665 & $5.6 \%$ & 142 & 135 & $5.1 \%$ \\
\hline NAMOR & 0.18 & 0.19 & $5.3 \%$ & 27.0 & 29.0 & $6.9 \%$ & 715 & 656 & $9.0 \%$ & 148 & 139 & $6.5 \%$ \\
\hline QOMS & 0.18 & 0.17 & $5.9 \%$ & 21.0 & 20.0 & $5.0 \%$ & 700 & 678 & $3.2 \%$ & 180 & 169 & $6.5 \%$ \\
\hline SETS & 0.18 & 0.17 & $5.9 \%$ & 25.0 & 27.0 & $7.4 \%$ & 751 & 724 & $3.7 \%$ & 92 & 87 & $5.7 \%$ \\
\hline October & \multicolumn{3}{|c|}{$r_{0(-)}$} & \multicolumn{3}{|c|}{$T_{\mathrm{S}}\left({ }^{\circ} \mathrm{C}\right)$} & \multicolumn{3}{|c|}{$R_{n}\left(\mathrm{Wm}^{-2}\right)$} & \multicolumn{3}{|c|}{$G_{0}\left(\mathrm{Wm}^{-2}\right)$} \\
\hline Sites & Cal. & Meas. & APD & Cal. & Meas. & APD & Cal. & Meas. & APD & Cal. & Meas. & APD \\
\hline Haibei & 0.16 & 0.17 & $5.9 \%$ & 3.0 & 3.0 & $0.0 \%$ & 478 & 456 & $4.8 \%$ & 82 & 77 & $6.5 \%$ \\
\hline Maqu & 0.18 & 0.19 & $5.3 \%$ & 24.0 & 26.0 & $7.7 \%$ & 476 & 434 & $9.7 \%$ & 93 & 86 & $8.1 \%$ \\
\hline D105 & 0.23 & 0.21 & $9.5 \%$ & 15.0 & 16.0 & $6.3 \%$ & 465 & 432 & $7.6 \%$ & 100 & 91 & $9.9 \%$ \\
\hline Amdo & 0.21 & - & - & 19.0 & 21.0 & $9.5 \%$ & 475 & - & - & 107 & 116 & $7.8 \%$ \\
\hline NPAM & 0.17 & 0.16 & $6.3 \%$ & 14.0 & 13.0 & $7.7 \%$ & 516 & 527 & $2.1 \%$ & 73 & 67 & $9.0 \%$ \\
\hline BJ & 0.21 & 0.20 & $5.0 \%$ & 20.0 & 21.0 & $4.8 \%$ & 443 & 406 & $9.1 \%$ & 126 & 117 & $7.7 \%$ \\
\hline NAMOR & 0.33 & - & - & -1.0 & -1.0 & $0.0 \%$ & 479 & - & - & 93 & 85 & $9.4 \%$ \\
\hline QOMS & 0.23 & 0.25 & $8.0 \%$ & 17.0 & 16.0 & $6.3 \%$ & 448 & 424 & $4.7 \%$ & 132 & 136 & $2.9 \%$ \\
\hline SETS & 0.16 & 0.17 & $5.9 \%$ & 22.0 & 24.0 & $8.3 \%$ & 472 & - & - & 83 & 76 & $9.2 \%$ \\
\hline
\end{tabular}


Table 2. Comparison of the derived sensible heat flux and latent heat flux (Cal.) versus the values measured (Meas.) at the Tibetan Plateau with absolute percent difference (APD).

\begin{tabular}{|c|c|c|c|c|c|c|c|c|c|c|c|c|}
\hline \multirow[b]{2}{*}{ Sites } & \multicolumn{6}{|c|}{ January: $H\left(\mathrm{Wm}^{-2}\right) \lambda E\left(\mathrm{Wm}^{-2}\right)$} & \multicolumn{6}{|c|}{ April: $H\left(\mathrm{Wm}^{-2}\right) \lambda E\left(\mathrm{Wm}^{-2}\right)$} \\
\hline & Cal. & Meas. & APD & Cal. & Meas. & APD & Cal. & Meas. & APD & Cal. & Meas. & APD \\
\hline Haibei & 197 & 211 & $6.6 \%$ & 138 & 146 & $5.5 \%$ & 400 & 381 & $5.0 \%$ & 264 & 268 & $1.5 \%$ \\
\hline Maqu & 155 & 142 & $9.2 \%$ & 36 & 33 & $9.1 \%$ & 286 & 296 & $3.4 \%$ & 156 & 143 & $9.1 \%$ \\
\hline D105 & 281 & 267 & $5.2 \%$ & 20 & 19 & $5.3 \%$ & 283 & 289 & $2.1 \%$ & 153 & 148 & $3.4 \%$ \\
\hline Amdo & 267 & 275 & $2.9 \%$ & 16 & 15 & $6.7 \%$ & 298 & 307 & $3.0 \%$ & 142 & 135 & $5.2 \%$ \\
\hline NPAM & 281 & 264 & $6.4 \%$ & 28 & 30 & $6.7 \%$ & 378 & 395 & $4.3 \%$ & 124 & 114 & $8.8 \%$ \\
\hline BJ & 176 & 192 & $8.3 \%$ & 12 & 11 & $9.1 \%$ & 342 & 355 & $3.7 \%$ & 119 & 127 & $6.3 \%$ \\
\hline NAMOR & 267 & 270 & $1.1 \%$ & 17 & 16 & $6.3 \%$ & 172 & 169 & $1.8 \%$ & 176 & 181 & $2.8 \%$ \\
\hline QOMS & 225 & 244 & $7.8 \%$ & 46 & 42 & $9.5 \%$ & 142 & 148 & $4.1 \%$ & 37 & 40 & $7.5 \%$ \\
\hline \multirow[t]{2}{*}{ SETS } & 267 & 252 & $6.0 \%$ & 19 & 18 & $5.6 \%$ & 139 & 144 & $3.5 \%$ & 145 & 141 & $2.8 \%$ \\
\hline & \multicolumn{6}{|c|}{ August: $H\left(\mathrm{Wm}^{-2}\right) \lambda E\left(\mathrm{Wm}^{-2}\right)$} & \multicolumn{6}{|c|}{ October: $H\left(\mathrm{Wm}^{-2}\right) \lambda E\left(\mathrm{Wm}^{-2}\right)$} \\
\hline Sites & Cal. & Meas. & APD & Cal. & Meas. & APD & Cal. & Meas. & APD & Cal. & Meas. & APD \\
\hline Haibei & 120 & 111 & $8.1 \%-$ & 279 & 264 & $5.7 \%$ & 235 & 253 & $7.1 \%$ & 97 & 93 & $4.3 \%$ \\
\hline Maqu & 158 & - & - & 560 & - & - & 95 & 101 & $5.9 \%$ & 101 & 92 & $9.8 \%$ \\
\hline D105 & 174 & - & - & 349 & - & - & 342 & 347 & $1.4 \%$ & 82 & 78 & $5.1 \%$ \\
\hline Amdo & 162 & - & - & 398 & - & - & 137 & 131 & $4.6 \%$ & 90 & 86 & $4.4 \%$ \\
\hline NPAM & 160 & 176 & $9.1 \%$ & 575 & 603 & $4.6 \%$ & 398 & 420 & $5.5 \%$ & 170 & 158 & $7.6 \%$ \\
\hline BJ & 159 & 173 & $8.8 \%$ & 411 & 398 & $3.3 \%$ & 275 & 294 & $6.5 \%$ & 42 & 39 & $7.7 \%$ \\
\hline NAMOR & 129 & 141 & $8.5 \%$ & 468 & 506 & $7.5 \%$ & 102 & 96 & $6.3 \%$ & 57 & 54 & $5.6 \%$ \\
\hline QOMS & 77 & 82 & $6.1 \%$ & 220 & 201 & $9.5 \%$ & 137 & 140 & $2.1 \%$ & 26 & 24 & $8.3 \%$ \\
\hline SETS & 106 & 112 & $5.4 \%$ & 469 & 482 & $2.7 \%$ & 132 & 136 & $2.9 \%$ & 151 & 141 & $7.1 \%$ \\
\hline
\end{tabular}

pixels with a size of $1 \times 1 \mathrm{~km}^{2}$.The derived surface reflectance, surface temperature, net radiation flux, soil heat flux, sensible heat flux and latent heat flux can be validated by the field measurements. In situ data observed in nine stations of Haibei $\left(37.62^{\circ} \mathrm{N}, 101.30^{\circ} \mathrm{E}\right.$; elevation: $3220 \mathrm{~m}$; land-cover: grassy marshland), Maqu $\left(33.89^{\circ} \mathrm{N}\right.$, $102.14^{\circ} \mathrm{E}$; elevation: $3423 \mathrm{~m}$; land-cover: grassy marshland), D105 $\left(33.06^{\circ} \mathrm{N}, 91.94^{\circ} \mathrm{E}\right.$; elevation: $5039 \mathrm{~m}$; landcover: sparseness meadow), Amdo $\left(32.14^{\circ} \mathrm{N}, 91.37^{\circ} \mathrm{E}\right.$; elevation: $4695 \mathrm{~m}$; land-cover: grassy marshland), NPAM $\left(31.93^{\circ} \mathrm{N}, 91.71^{\circ} \mathrm{E}\right.$; elevation: $4620 \mathrm{~m}$; land-cover: grassy marshland $), \mathrm{BJ}\left(31.37^{\circ} \mathrm{N}, 91.90^{\circ} \mathrm{E}\right.$; elevation: $4509 \mathrm{~m}$; landcover: sparseness meadow), NAMOR(Nam Co Station for Multisphere Observation and Research, Chinese Academy of Sciences; $30.46^{\circ} \mathrm{N}, 90.59^{\circ} \mathrm{E}$; elevation: $4730 \mathrm{~m}$; land-cover: grassy marshland), QOMS(Qomolangma Station for Atmospheric and Environmental Observation and Research, Chinese Academy of Sciences; $28.21^{\circ} \mathrm{N}, 86.56^{\circ} \mathrm{E}$; elevation: $4276 \mathrm{~m}$; land-cover: sparse grass-Gobi) and SETS(Southeast Tibet Station for Alpine Environment Observation and Research, Chinese Academy of Sciences; $29.77^{\circ} \mathrm{N}, 94.73^{\circ} \mathrm{E}$; elevation: $3326 \mathrm{~m}$; land-cover: grass land) in the Tibetan Observation and Research Platform ( TORP, Ma et al., 2008) are used for the validation. In Tables 1, 2 and Fig. 5, the derived results are validated against the measured values in the stations. Since it is a little difficult to determine the loca- tions of the four stations, the values of $5 \times 5$ pixel rectangle, surrounding the determined Universal Transfer Macerator (UTM) coordinate, are compared with the in situ data. The absolute percent difference (APD) was quantitatively measures the difference between the derived results $\left(H_{\text {derived(i) }}\right)$ and measured value $\left(H_{\text {measured(i) }}\right)$ here, and

$\mathrm{APD}=\frac{\left|H_{\text {derived(i) }}-H_{\text {measured(i) }}\right|}{H_{\text {measured(i) }}}$

The results show that: (1) The derived surface reflectance $\left(r_{0}\right)$, surface temperature $\left(T_{\mathrm{sfc}}\right)$, net radiation heat flux $\left(R_{n}\right)$, soil heat flux $\left(G_{0}\right)$, sensible heat flux $(H)$ and latent heat flux $(\lambda E)$ for the Tibetan Plateau area are in good accordance with the land surface status, and they show a wide range due to the strong contrast of surface features over there (Figs. 1, 3 and 4). Surface reflectance is from 0.00 to 0.50 in January (some of the surface reflectance with value large than 0.50 indicating cloud-covering), it is from 0.00 to 0.45 in April (some of the surface reflectance with value large than 0.45 indicating cloud-covering), it is from 0.00 to 0.45 in August (some of the surface reflectance with value large than 0.45 indicating cloud-covering), it is from 0.00 to 0.50 in October (some of the surface reflectance with value large than 0.50 indicating cloud-covering) (Fig. 3); Surface temperature range from $-30^{\circ} \mathrm{C}$ to $20^{\circ} \mathrm{C}$ in January, it range from $-40^{\circ} \mathrm{C}$ to $36^{\circ} \mathrm{C}$ in April, it is from $-20^{\circ} \mathrm{C}$ to $55^{\circ} \mathrm{C}$ in $\mathrm{Au}-$ gust, and it is from $-30^{\circ} \mathrm{C}$ to $30^{\circ} \mathrm{C}$ in October (the blue parts 

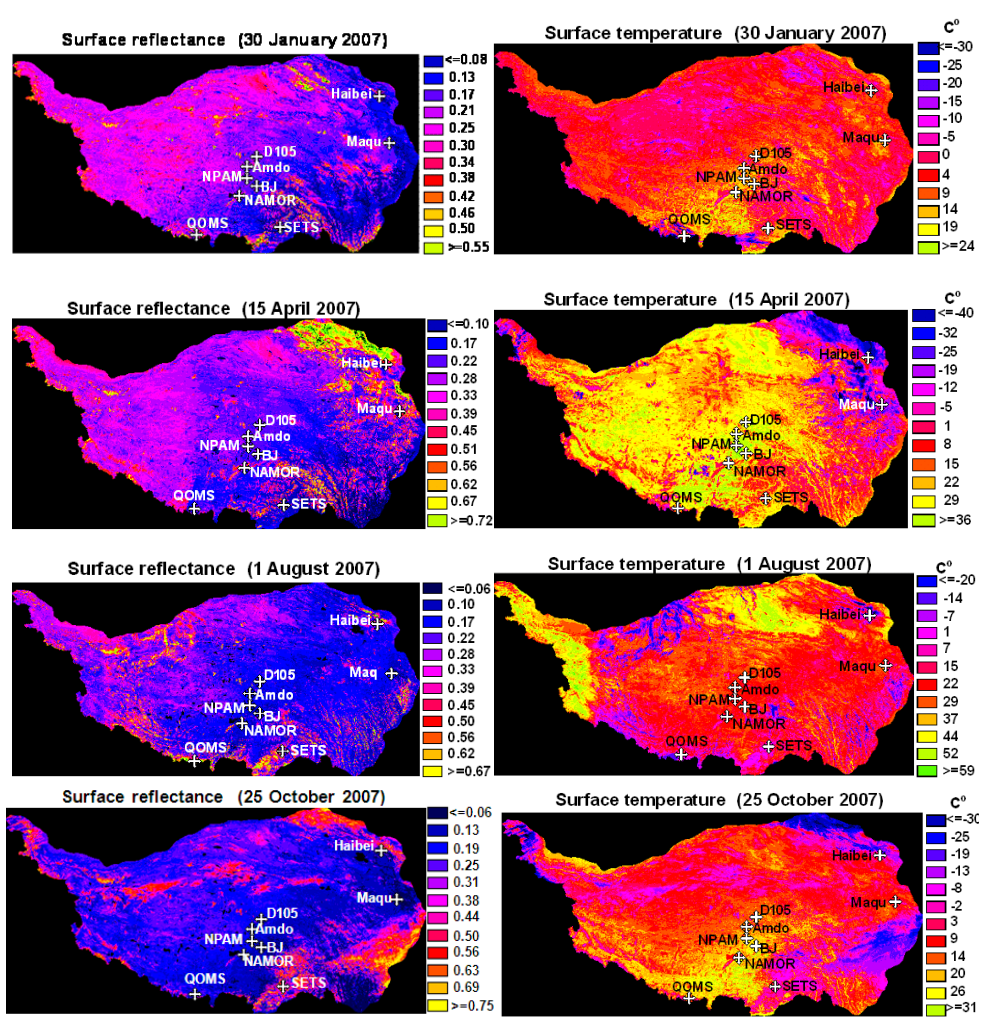

Fig. 3. The distribution maps of surface reflectance and surface temperature over the Tibetan Plateau area.
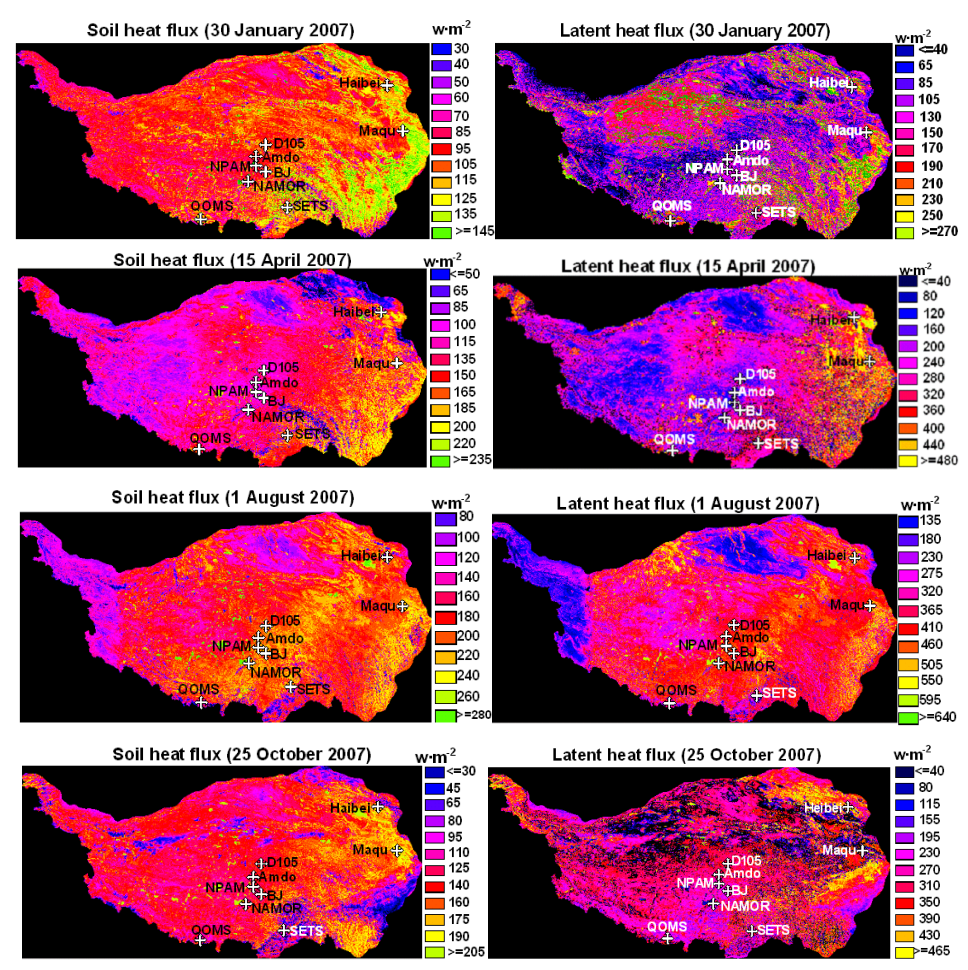

Fig. 4. The distribution maps of surface soil heat flux and latent heat flux over the Tibetan Plateau area. 

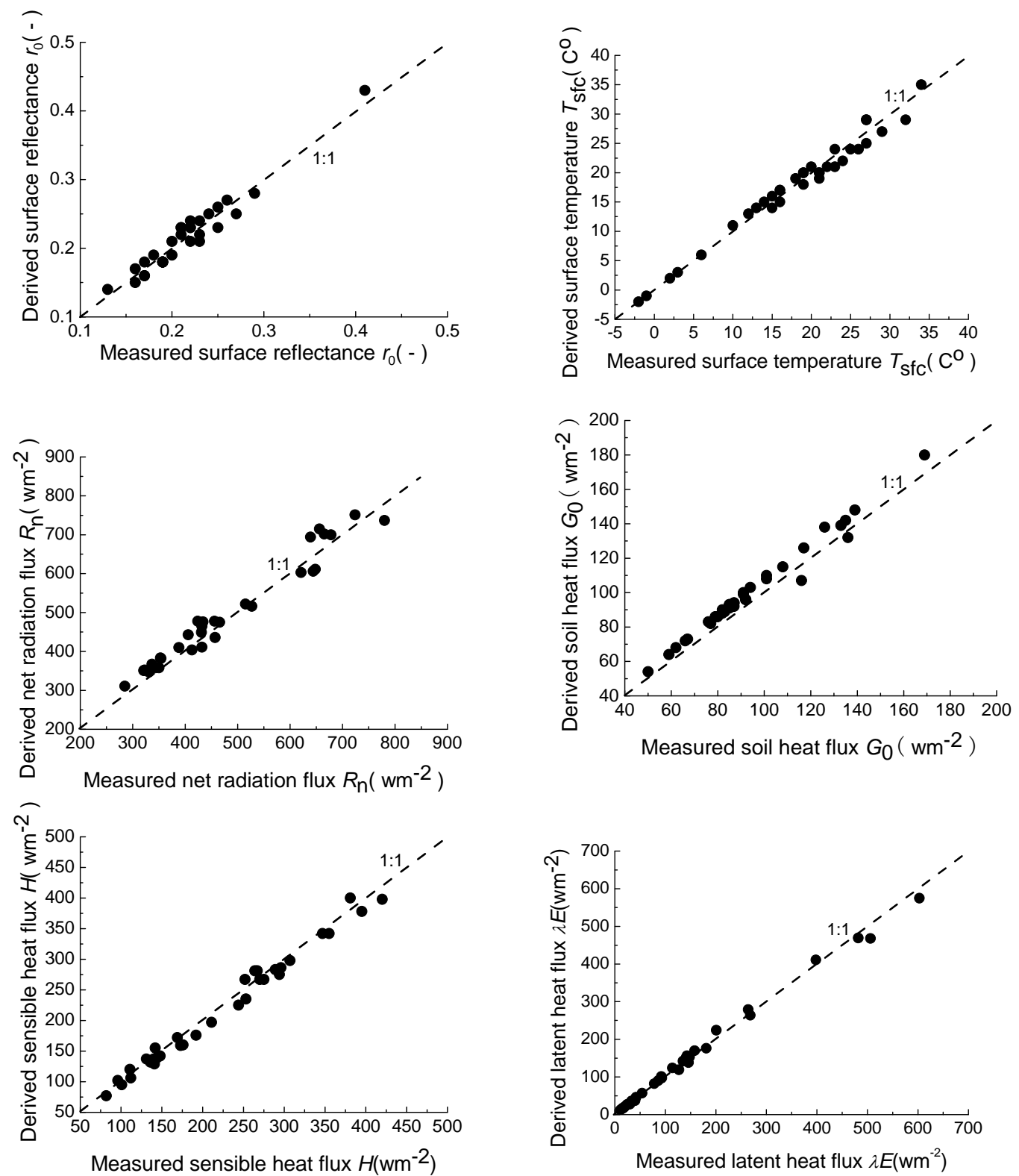

Fig. 5. Comparison of derived results with field measurements for the surface reflectance, surface temperature, net radiation flux, soil heat flux, sensible heat flux and latent heat flux over the Tibetan Plateau area, together with a 1:1 line.

in the distribution maps indicating cloud-covering) (Fig. 3); $R_{n}$ change from 115 to $550 \mathrm{~W} \mathrm{~m}^{-2}$ in January, it varies from 170 to $700 \mathrm{~W} \mathrm{~m}^{-2}$ in April, it is from 200 to $920 \mathrm{~W} \mathrm{~m}^{-2}$ in August, and varies from 100 to $700 \mathrm{~W} \mathrm{~m}^{-2}$ in October; $G_{0}$ varies from 30 to $140 \mathrm{~W} \mathrm{~m}^{-2}$ in January, it changes from 50 to $220 \mathrm{~W} \mathrm{~m}^{-2}$ in April, it is from 80 to $275 \mathrm{~W} \mathrm{~m}^{-2}$ in $\mathrm{Au}$ gust, and varies from 80 to $260 \mathrm{~W} \mathrm{~m}^{-2}$ in October (Fig. 4); $H$ change from 0 to $280 \mathrm{~W} \mathrm{~m}^{-2}$ in January, it varies from 0 to $300 \mathrm{~W} \mathrm{~m}^{-2}$ in April, it is from 0 to $200 \mathrm{~W} \mathrm{~m}^{-2}$ in August, and varies from 0 to $480 \mathrm{~W} \mathrm{~m}^{-2}$ in October; $\lambda E$ is from 40 to $250 \mathrm{~W} \mathrm{~m}^{-2}$ in January, it varies from 40 to $400 \mathrm{~W} \mathrm{~m}^{-2}$ in April, it change from 135 to $640 \mathrm{~W} \mathrm{~m}^{-2}$ in August, and varies from 40 to $450 \mathrm{~W} \mathrm{~m}^{-2}$ in October (Fig. 4); (2) the derived surface reflectance, surface temperature, net radiation flux, soil heat flux, sensible heat flux and latent heat flux over the Tibetan Plateau area are very close to the field measurements. The difference between the derived results and the field observation APD is less than $10 \%$ (Tables 1, 2 and Fig. 5). The reason is that accurate surface reflectance and surface temperature were determined and the process of atmospheric boundary layer was considered in more detail in the determination of sensible heat flux in the procedure; and 
(3) The mean net radiation flux over the TP area is increasing from January to April and August, then decreasing from October. They are $415 \mathrm{~W} \mathrm{~m}^{-2}, 487 \mathrm{~W} \mathrm{~m}^{-2}, 630 \mathrm{~W} \mathrm{~m}^{-2}$ and $505 \mathrm{~W} \mathrm{~m}^{-2}$; The mean surface soil heat flux over the TP area is increasing from January to April and August, then decreasing from October. They are $99 \mathrm{~W} \mathrm{~m}^{-2}, 125 \mathrm{~W} \mathrm{~m}^{-2}$, $175 \mathrm{~W} \mathrm{~m}^{-2}$ and $131 \mathrm{~W} \mathrm{~m}^{-2}$; The mean sensible heat flux over the TP area is decreasing from January to April and August, then increasing from October. They are $190 \mathrm{~W} \mathrm{~m}^{-2}$, $142 \mathrm{~W} \mathrm{~m}^{-2}, 114 \mathrm{~W} \mathrm{~m}^{-2}$ and $192 \mathrm{~W} \mathrm{~m}^{-2}$; The mean latent heat flux over the TP area is increasing from January to April and August, then decreasing from October. They are $141 \mathrm{~W} \mathrm{~m}^{-2}, 254 \mathrm{~W} \mathrm{~m}^{-2}, 350 \mathrm{~W} \mathrm{~m}^{-2}$ and $278 \mathrm{~W} \mathrm{~m}^{-2}$.

\section{Concluding remarks}

In this study, the regional distributions of surface reflectance, surface temperature, net radiation flux, soil heat flux sensible heat flux and latent heat flux over heterogeneous landscape of the Tibetan Plateau are derived with the aid of MODIS and the in situ data. Compared with the field measurements, the proposed methodology has been proved to be a better approach to getting related land surface heat fluxes over heterogeneous landscape. It forms a sound basis to study the exchange processes of heat and water on heterogeneous land surface.

Regionalization the net radiation heat flux, soil heat flux, sensible heat flux and latent heat flux over heterogeneous landscape is not an easy issue. The parameterization methodology presented in this research is still in developing stage due to only a single set of values at a specific time of specific day are used in this research. To reach more accurate regional land surface heat fluxes over the Tibetan Plateau area, more field observations, more accurate radiation transfer models to determine the surface reflectance and surface temperature, and another satellites such as GMS (Geo-stationary Meteorological Satellite), ATSR (Along Track Scanning Radiometer) and AVHRR (Advanced Very High-Resolution Radiometer) have to be used. These research works will be done in the next step.

Acknowledgements. This work was under the auspices of the Chinese National Key Programme for Developing Basic Sciences (2010CB951701), the National Natural Foundation of China (40825015 and 40810059006), the Innovation Projects of the Chinese Academy of Sciences (KZCX2-YW-Q11-01), and EU-FP7 project "CEOP-AEGIS"(212921). Most work was finished in the University of Bayreuth with Prof. Thomas Foken and his group and in the University of Tokyo. The in situ data of Haibei station and Maqu station was come from Yingnian Li, Xinqaun Zhao and Yu Zhang.

Edited by: Q. Fu

\section{References}

Bastiaanssen, W. G. M.: Regionalization of surface fluxes and moisture indicators in composite terrain, $\mathrm{PhD}$ Thesis, Wageningen Agricultural University, 273 pp., 1995.

Berk, A., Bernstein, L. S., and Robertson, D.C.: MODTRAN: A moderate resolution model for LOTRAN 7. GL-TR-89-0122, 1989.

Carlson, T. N. and Ripley, D. A.: On the relation between NDVI, fractional vegetation cover, and leaf area index, Remote Sens. Environ., 62, 241-252.1997,

Choudhury, B. J. and Monteith, J. L.: A four-layer model for the heat budget of homogeneous land surfaces, Q. J. Roy. Meteor. Soc., 114, 373-398, 1988.

Choudhury, B. J., Idso, S. B., and Reginato, R. J.: Analysis of an empirical model for soil heat flux under a growing wheat crop for estimating evaporation by infrared-temperature based energy balance Eq., Agr. Forest. Meteorol., 39, 283-297, 1987.

Cui, X. and Graf, H.: Recent land cover changes on the Tibetan Plateau: a review, Climatic Change, 94, 47-61, 2009.

Gao, Z., Horton, R., and Liu, H.: Impact of wave phase difference between soil surface heat flux and soil surface temperature on soil surface energy balance closure, J. Geophysics Research, 115, D16112, doi:10.1029/2009JD013278, 2010.

Hsu, H. and Liu, X.: Relationship between the Tibetan Plateau heating and East Asian summer monsoon rainfall, Geophys. Res Lett., 30, D2066, doi:10.1029/2003GL017909, 2003.

Jackson, R. D., Pinter, J. R., and Reginato, R. J.: Net radiation calculated from remote multispectral and ground station meteorological data, Agr. Forest. Meteorol., 35, 153-164, 1985.

Kustas, W. P. and Daughtry, C. S. T.: Estimation of the soil heat flux/net radiation ratio from spectral data, Agr. Forest. Meteorol., 39, 205-223, 1990.

Ma, Weiqiang, Ma, Yaoming, Li, Maoshan, Hu, Zeyong, Zhong, Lei, Su, Zhongbo, Ishikawa, Hirohiko, and Wang, Jiemin: Estimating surface fluxes over the north Tibetan Plateau area with ASTER imagery, Hydrol. Earth Syst. Sci., 13, 57-67, doi:10.5194/hess-13-57-2009, 2009.

Ma, Y. and Tsukamoto, O.: Combining satellite remote sensing with field observations for land surface heat fluxes over inhomogeneous landscape, China Meteorological Press, Beijing, China, 2002.

Ma, Y., Tsukamoto, O., Wang, J., Ishkawa, H., and Tamagawa, I.: Analysis of aerodynamic and thermodynamic parameters over the grassy marshland surface of Tibetan Plateau, Prog. Nat. Sci., 12, 36-40, 2002a.

Ma, Y., Su, Z., Li, Z.-L., Koike, T., and Menenti, M.: Determination of regional net radiation and soil heat flux densities over heterogeneous landscape of the Tibetan Plateau, Hydrol. Process., 16, 2963-2971 2002b.

Ma, Y., Ishikawa, H., Menenti, M., Su, Z., Yao, T., Koike, T., and Yasynari, T.: Regionalization of surface fluxes over heterogeneous landscape of the Tibetan Plateau by using satellite remote sensing, J. Meteorol. Soc. Jpn., 81, 277-293, 2003.

Ma, Y., Zhong, L., Z. Su, Z., Ishikawa, H., Menenti, M., and Koike, T.: Determination of regional distributions and seasonal variations of land surface heat fluxes from Landsat-7 Ehanced Thematic Mapper data over the central Tibetan Plateau area, J. Geophys. Res.-Atmos., 111, D10305, doi:10.1029/2005JD006742, 2006. 
Ma, Y., Song, M., Ishikawa, H., Yang, K., Koike, T., Jia, L., Menenti, M., and Su, Z.: Estimation of the regional evaporative fraction over the Tibetan Plateau area by using Landsat-7 ETM data and the field observations, J. Meteorol. Soc. Jpn., 85A, 295309, 2007.

Ma, Y., Kang, S., Zhu, L., Xu, B., Tian, L., and Yao, T.: Tibetan Observation and Research Platform- Atmosphere-land interaction over a heterogeneous landscape, Bull. Amer. Meteor. Soc., 89, 1487-1492, 2008.

Ma, Y., Menenti, M., and Feddes, R.: Parameterization of heat fluxes at heterogeneous surfaces by integrating satellite measurements with surface layer and atmospheric boundary layer observations, Adv. Atmos. Sci., 27, 328-336, 2010.

Montheith, J. L.: Principles of Environmental Physics, Edward Aarnold, London, 241 pp., 1973.

Sato, T. and Kimura, F.: How does the Tibetan Plateau affect the transition of Indian monsoon rainfall? Mon. Weather Rev., 135, 2006-2015 2007,

Valor, E. and Caselles, V.: Mapping land surface emissivity from NDVI: application to European, African, and South American areas, Remote Sens. Environ., 57, 167-184, 1996,

Wang, J., Ma, Y., Menenti, M., Bastiaanssen, W., and Mistuta, Y.: The scaling-up of processes in the heterogeneous landscape of HEIFE with the aid of satellite remote sensing, J. Meteorol. Soc. Jpn., 73, 1235-1244, 1995.
Yanai, M., Li, C., and Song, Z.: Seasonal heating of the Tibetan Plateau and its effects on the evolution of the Asian summer monsoon, J. Meteorol. Soc. Jpn., 70, 319-351, 1992.

Yang, K., Koike, T., Ishikawa, H., and Ma, Y.: Analysis of the surface energy budget at a site of GAME/Tibet using a single-source model, J. Meteorol. Soc. Jpn., 82, 131-153, 2004.

Ye, D.: Some characteristics of the summer circulation over the Qinghai-Xizang (Tibet) Plateau and its neighborhood, B. Am. Meteorol. Soc., 62, 14-19, 1981.

Ye, D. and Gao, Y.: The Meteorology of the Qinghai-Xizang (Tibet) Plateau , 1-278, Science Press, Beijing, 1979 (in Chinese).

Ye, D. and Wu, G.: The role of the heat source of the Tibetan Plateau in the general circulation, Meteorol. Atmos. Phys., 67, 181-198, 1998.

Zhong, L.: Measurement and satellite remote sensing of land surface characteristic parameters over the Tibetan Plateau area, $\mathrm{PhD}$ Thesis, Graduate University of Chinese Academy of Sciences, 124 pp., 2007.

Zhong, L., Ma, Y., Salama, Mhd.Suhyb, and Su, Z.: Assessment of vegetation dynamics and their response to variations in precipitation and temperature in the Tibetan Plateau, Climatic Change, doi:10.1007/s10584-009-9787-8, 2010. 